\title{
A Functional Analysis of Prepositional Phrases in Persian
}

\author{
Vali Rezai (Corresponding author) \\ University of Isfahan \\ E-mail: vali.rezai@fgn.ui.ac.ir \\ Homayoon Saeedi \\ University of Isfahan \\ E-mail:hn_saeedi@yahoo.com
}

Received: September 18, 2012 Accepted: October 9, 2012 Published: December 1, 2012

doi:10.5296/ijl.v4i4.2405

URL: http://dx.doi.org/10.5296/ijl.v4i4.2405

\begin{abstract}
Prepositional phrases may take different roles in Persian sentences as independent constituents. They can also act as constituents dependent to nominal, adjectival and adverbial phrases. Role and Reference Grammar presents a general classification of prepositional phrases. This classification is applied to prepositional phrases in Persian in this paper. In this theory, prepositions are categorized as either predicative or non-predicative. The former provides semantic information for the clause in which it occurs. The latter bear no semantic information for the clause and the nominal phrase occurring with them is determined by the predicate.The prepositional phrases are also classified into three groups of adjunct prepositional phrases, argument -marking, and argument- adjunct. In the first group, the predicative prepositions as heads, take the syntactic adjunct position. In the second group, the non-predicative prepositions don't add substantial semantic information to the clause and the nominal phrase occurring with them is determined by the predicate. It means that the prepositional phrase is one of the arguments of the predicate. The third group contains predicative prepositions that add to the meaning of the sentence. In addition, argument-adjunct prepositional phrases introduce one of the participants in the event. This study demonstrates that the prepositional phrases in Persian have different functions. They not only take an adjunctive role but also act as argument for the predicates of different kinds
\end{abstract}




\section{Macrothink}

International Journal of Linguistics

ISSN 1948-5425 2012, Vol. 4, No. 4

in this language. Ultimately, we conclude that Role and Reference Grammar accounts for prepositional phrases in Persian.

Keywords: Prepositional phrases, Adjunct prepositional phrases, Argument-marking prepositional phrases, Argument -adjunct prepositional phrases 


\section{Macrothink}

\section{Introduction}

Prepositional phrases have a high frequency in Persian language sentences. The following sentences (1-3) show some of their functions as an independent constituent.

1) Ahmad dar ketâbxâne dars mi-xânad.

Ahmad in library lesson IMPR- study.

'Ahmad studies in the library.'

2) Hossein ketâb râ be dust-aš dâd.

Hossein book DO to friend-his gave.

'Hossein gave the book to his friend.'

3) Iran be dânešmandân-aš eftexâr mi-konad.

Iran to scientists -its proud IMP-do

'Iran is proud of its scientists.'

Prepositional phrases are used as dependent constituents too. The sentences (4-6) illustrate this function.

4) Mosâhebe bâ ostâd jâleb bud.

interview with professor interesting was.

'The interview with the professor was interesting.'

5) Ali az barâdar-aš bozorg-tar ast.

Ali from brother-his old-COMP is.

'Ali is older than his brother.'

6) Xâhar-am biš-tar az man dars mi-xânad.

sister-my more-COMP from I lesson IMP-study

'My sister studies more than I.'

Linguists and grammarians hold different views concerning prepositional phrases in Persian language. For example (Bateni, 1996:77) considers the prepositional phrases as adverbial phrases and believes they take an adjunctive role in clause structure. As another example, prepositional phrases in the following two sentences (7-8) are called indirect objects(Gharib et al2002: 222, Arzhang 1996: 24). Whereas the prepositional phrase is ignorable in the first sentence and it takes an adjunctive role also, the indirect object in the second sentence cannot be omitted. These different points of view necessitate more research in this field. In the 
present study, we try to investigate independent Persian prepositional phrases within the framework of Role and Reference Grammar.

7) Houšang diruz ketâb râ be xâne bord.

Houshang yesterday book DO to home took.

'Houshang took the book home yesterday.'

8) Man bâ u nabard kardam

I with s/he fight did.

'I fought him/her.'

\section{Introducing Role and Reference Grammar}

Role and Reference Grammar is a functional theory of grammar which was developed primarily by Van Valin and Foley (1980) and Foley and VanValin (1984). The most comprehensive versions of this syntactic theory is presented in VanValin and LaPolla (1997), VanValin(2005) and VanValin (2008). RRG holds that language is primarily a tool for verbal communication. Accordingly, sentences are described in the first place in terms of their semantic and communicative functions. Role and Reference Grammar was inspired by typological studies, hence it considers the typological adequacy in linguistic theorizing and avoid an English biased perspective on grammatical structure, as is typical of many other theories. RRG is a monostratal theory. The syntactic representation of a sentence corresponds to its actual structure, including actual word order and morphology, it is connected to the semantic representation through discourse pragmatic principles (Luraghi and Parodi, 2008: 40)

Role and Reference Grammar incorporates many of the points of view of current functional grammar theories. The description of a sentence in a particular language is formulated in terms of (a) its logical (semantic) structure and communicative functions, and (b) the grammatical procedures that are available in the language for the expression of these meanings. Among the main features of RRG are the use of lexical decomposition, based upon the predicate semantics of Dowty (1979), an analysis of clause structure, and the use of a set of thematic roles organized into a hierarchy in which the highest-ranking roles are 'Actor' (for the most active participant) and 'Undergoer'.

\subsection{Semantic and Syntactic Structure}

There are certain semantic categories in all languages. However, the way languages of the world express these categories in their syntax, is different. The main semantic distinctions found in all languages include predicates, their arguments and non-argument elements. Predicates describe the event or situation and is often (not always) expressed by a verb. Arguments represent the participants in that action or event and are referring expressions that are often expressed by noun phrases. Non-argument elements bear temporal or locational information about an event or situation. 
The figure below shows the universal semantic elements.

\begin{tabular}{|l|l|}
\hline Predicate + arguments & Non-arguments \\
\hline
\end{tabular}

The main syntactic constituents that correspond to them are the nucleus, which contains the predicate, the core, which contains the nucleus and its arguments, and a periphery, which contains non-arguments, phrases and words that modify the whole core. For example the sentence below is analyzed as follows:

9) Hasan dust-aš râ dar dânešgâh did.

Hasan friend-his DO in university saw.

'Hasan saw his friend in the university.'

The first thing to do is to locate the predicate. The verb did is the semantic predicate and this will form the syntactic nucleus of the sentence, hasan and dustaš are its arguments and these three constituents form the core of the sentence. The optional locative prepositional phrase dar dânešgâh which places the event in space, is in the syntactic periphery. It is worth noticing that this analysis is not based on word class (noun, verb, etc.), but rather on function. The syntactic arguments that appear in the core are called core arguments which may be either direct or oblique. The direct core arguments are those that don't come along with prepositions in languages like English. The oblique core arguments are determined by prepositions.

There are some specific semantic arguments that have the same syntactic behavior. The groups of arguments that take the syntactic role of subject are usually agent in semantics. The groups of arguments that take the syntactic role of object play a role similar to patient. Here we use generalized roles, meaning, the arguments of agent type are called actor and the arguments of patient type are called undergoer. These roles are called macrorole since each of them includes specific semantic roles. The actor may be the agent, the instrument or the experiencer, whereas the undergoer may be the patient, theme or recipient. These roles are presented in the sentences below.

9) Ali dar râ bâ kelid bâz kard.

Ali door DO with key open did.

'Ali opened the door with a key.'

10) Kelid dar râ bâz kard.

key door DO open did.

'The key opened the door.'

11) Man sedâ râ šenidam.

I voice DO heard. 
'I heard the voice.'

In the above sentences, Ali, kelid and man, take the semantic roles agent, instrument and experiencer, respectively. However, all these noun phrases are actor.

In some cases, predicates may have only one argument and that single argument could be either actor or undergoer.

12) Ahmad mi-davad.( actor)

Ahmad IMP-run

'Ahmad runs.'

13)Yax zob mi-šavad.( undergoer)

ice melt IMP-become

'The ice melts.'

It should be mentioned though that the semantic roles, actor and undergoer are not equivalent to subject and object in other syntactic theories. This can be illustrated by the following sentences.

14) Kudak goldân râ šekast.

child vase DO broke.

'The child broke the vase.'

15) Goldân šekaste šod.

vase broken became.

'The vase was broken.'

In the sentence (14) kudak is the actor and goldân is the undergoer, whereas in (15) the undergoer takes the subject slot. We now close this brief introduction to Role and Reference Grammar quoting the following sentences from Van valin \& Lapola (1997:22) and Pavey(2010:53).

"A theory of syntax should capture all of the universal features of clauses without imposing features on languages that show no evidence for them and represent comparable structures in different languages in comparable ways.”

\subsection{Classifications of Prepositional Phrases}

Whether they come with predicative or non-predicative prepositions, prepositional phrases are classified in two classes in Role and Reference Grammar theory. Predicative prepositions function like predicates in that they contribute substantive semantic information to the clause in which they occur, both in terms of their own meaning and the meaning of the argument that they license (Van valin 2005:22). Non-predicative prepositions do not add any substantive semantic information to the clause and do not license the argument they mark. 
Rather, their argument is licensed by the predicate, i.e., it is a core argument, these prepositions are a function of the semantics of the predicate and are in effect free-morphemic case markers assigned by it(Van valin 2005:23). There is also a difference between the prepositional phrases which are main predicate argument and those which are not. Three types of prepositional phrases are as follows.

\subsubsection{Adjunct Prepositional Phrase}

In these phrases predicative prepositions function like predicates, they provide semantic information for the clause they appear in. The semantic information is based on the prepositions meaning and the noun phrase that comes after them as well. This can be illustrated by the following sentence.

16) I am watching TV after work.

As it can be seen, the prepositional phrase after work in (16) carries information about the time of the event.

\subsubsection{Argument-marking Prepositional Phrases}

Unlike the already mentioned group, this one is non-predicative. Here, the preposition doesn't add any semantic meaning itself and cannot be replaced by another preposition since the preposition selection is determined by the semantic role of the noun phrase that comes with it.

17) I took the phone from my sister.

\subsubsection{Argument- Adjunct Prepositional Phrases}

This class contains predicative prepositions that add to the meaning of the sentence. In addition, argument-adjunct prepositional phrases introduce one of the participants in the event. This is illustrated by the following sentence.

18) She put the flowers in the vase.

\section{Analyzing the Prepositional Phrases in Persian}

As already observed in Section (2.2), the classification of the prepositional phrases in Role and Reference Grammar includes those that are independent structures. In that light, we only analyze the independent prepositional phrases in Persian. The nature of the distinction between arguments and adjuncts and the criteria for identifying them have been a longstanding point of controversy in grammatical theory. (Croft 2001, Van valin 2001, Dowti 2003).

Arguments are syntactically and semantically closer to their head, e.g., the lexical verb by which they are selected, and are part of its lexical entry .They are obligatory constituents. Adjuncts are not part of the lexical entry of verb and are not selected by it. They describe the temporal, spatial or manner settings or circumstances in which the situation described by the verb takes place, and are therefore optional. (Cennamo \& Lenci2011). In the following 
section a general scheme of the functions of the prepositional phrases is presented based on their three main features:

a: the semantic nature of the prepositional phrases (+/- argument)

b: their syntactic behavior (+/- core)

c: the nature of their prepositions (+/- predicative)

The combination of these features yields a system of different logical PP types which are exemplified with data from Persian. The Role and Reference Grammar, considers lexical semantics as a start point in analyzing a clause. In an analysis based on this theory, validity of a participant element as either an adjunct or an argument is a function of verb semantics.

\subsection{Adjunct Prepositional Phrases (- argument), (- core), (+ predicative).}

In Role and Reference Grammar, the distinction between core and periphery is based on a differentiation between arguments and non-arguments. Two types of non-arguments or adjuncts are phrasal adjuncts such as prepositional phrases and non-phrasal adjuncts such as adverbs. The adjuncts in prepositional phrases describe the core and mostly appear in the periphery. Some adverbs such as adverbs of time, also describe core, and appear in the periphery. These groups are common peripheral participants of clause. Known examples are time and place prepositional phrases. In these groups, preposition is the nucleus of the prepositional phrase that has taken the syntactic slot of adjunct. These prepositional phrases are adjuncts (or adverbials), elements that modify in some way the event or situation described by the main predicate.

Adjuncts determine the time, place, etc properties of the situation presented by the predicate. They include marginal and extra information and their omission won't disturb the structure of the sentence, meaning, their deletion will decrease the richness of the information provided by the sentence but have not any influence on its well-formedness.

19) Man moallem-am râ dar xiyabân didam.

I teacher-my DO in street saw.

'I saw my teacher in the street.'

20) Man baad az kar-e ruzâne televizion tamâša mi-konam.

I after work-EZ daily television watch IMP-do

'I watch television after daily work.'

In the above sentences the preposition contributes to the meaning of the sentence (location or the time of the event). The fact that how the preposition does this can be figured out by changing the preposition and seeing how the meaning of the sentence changes.

21) ketâb ruye/zire/kenâre miz ast.

book on/under/beside table is. 
'The book is on/under/beside the table.'

These prepositional phrase types have an internal constituent structure.

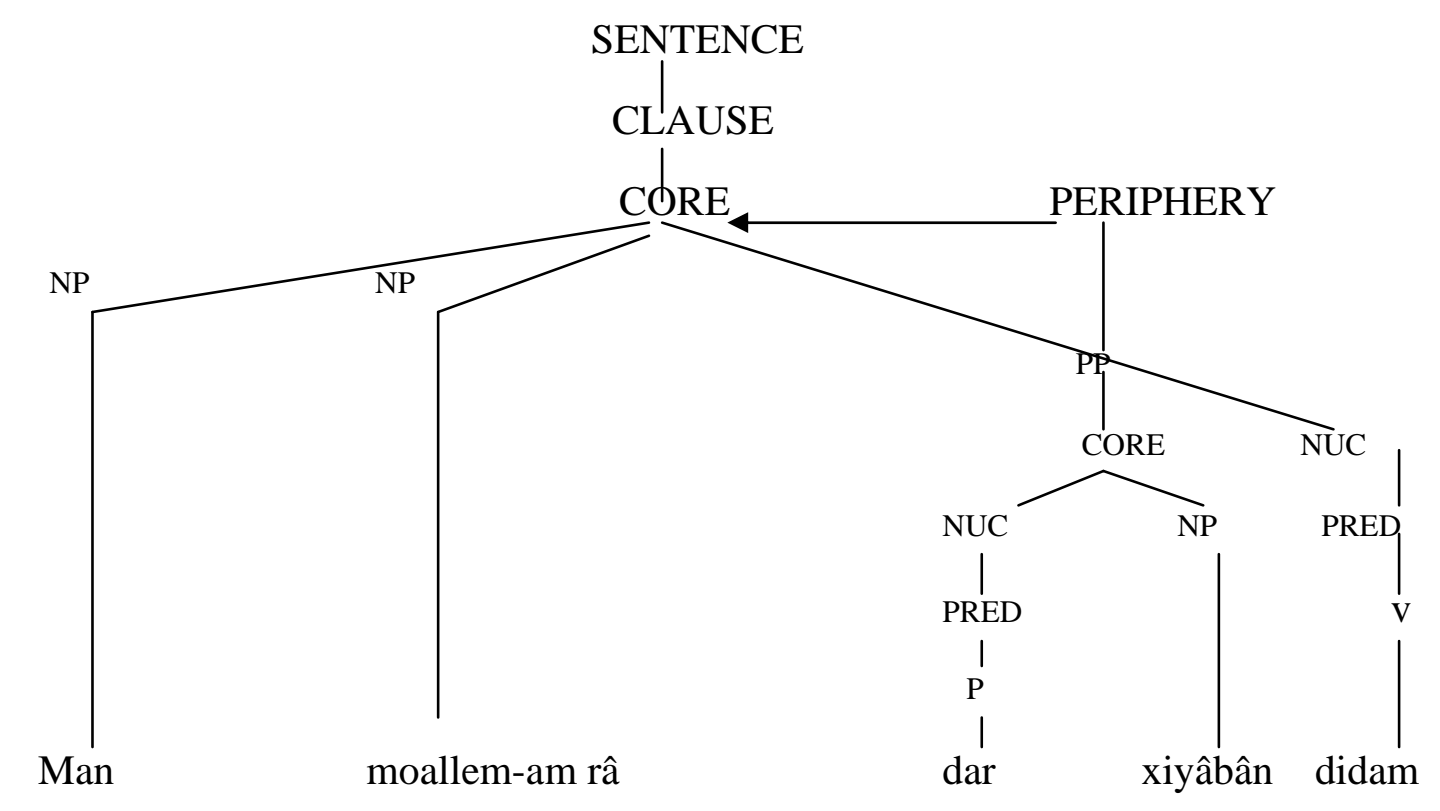

Figure 1. Syntactic representation of an adjunct prepositional phrase

Regarding the Persian language corpuses, these groups have the highest frequency in Persian sentences and play an important part in conveying the speakers' intended thoughts and concepts.

3.2 Argument-marking Prepositional Phrases (+ argument), (+ core), (- predicative preposition).

As Van valin (2005:22) suggests, the non-predicative prepositions, don't add semantic information to the sentence and the noun phrase exceeds them is determined by the predicate; so they are the core argument. These prepositions are a function of predicate semantics and are determined by it. In Role and Reference Grammar terminology, these groups are usually called the oblique core argument. In other words, preposition determines the non-macrorole argument which is neither actor nor undergoer. The direct core arguments are those that are not marked by prepositions. They are actors and undergoers. Clearer examples of oblique core arguments are recipient argument of transfer verbs in languages like Persian and English.

22) Ali ketâb râ be Maryam dâd.

Ali book DO to Maryam gave.

'Ali gave the book to Maryam.'

23) Man ketâb-am râ be/az*/dar* Ali dâdam.

I book-my DO to/from*/in* Ali gave. 
'I gave my book to/*from/*in Ali.'

In languages that do not use case marking for this purpose, argument-marking prepositions mark oblique core arguments of the predicate with a preposition.

24) Xâne râ be barâdar-am sepordam.

house DO to brother-my trusted-1.SG.

'I trusted the house to my brother.'

25) In nokte râ az ostâd âmuxtam.

this point DO from professor learnt-1.SG.

'I learnt this point from the professor.'

Core arguments that are not marked with prepositions, are direct core arguments. The predicates sepordan, âmuxtan, baxšidan, in the above sentences have three arguments. The third argument is determined by the preposition, in other words, it marks the non- macrorole argument that is neither the actor nor the undergoer.

26) Pedar-am in xâne râ be man baxšid.

father-my this house DO to I granted.

'My father granted this house to me.'

The underlined noun phrase in the above sentence possesses the semantic role of receiver which in Persian is determined by the preposition $b e$.

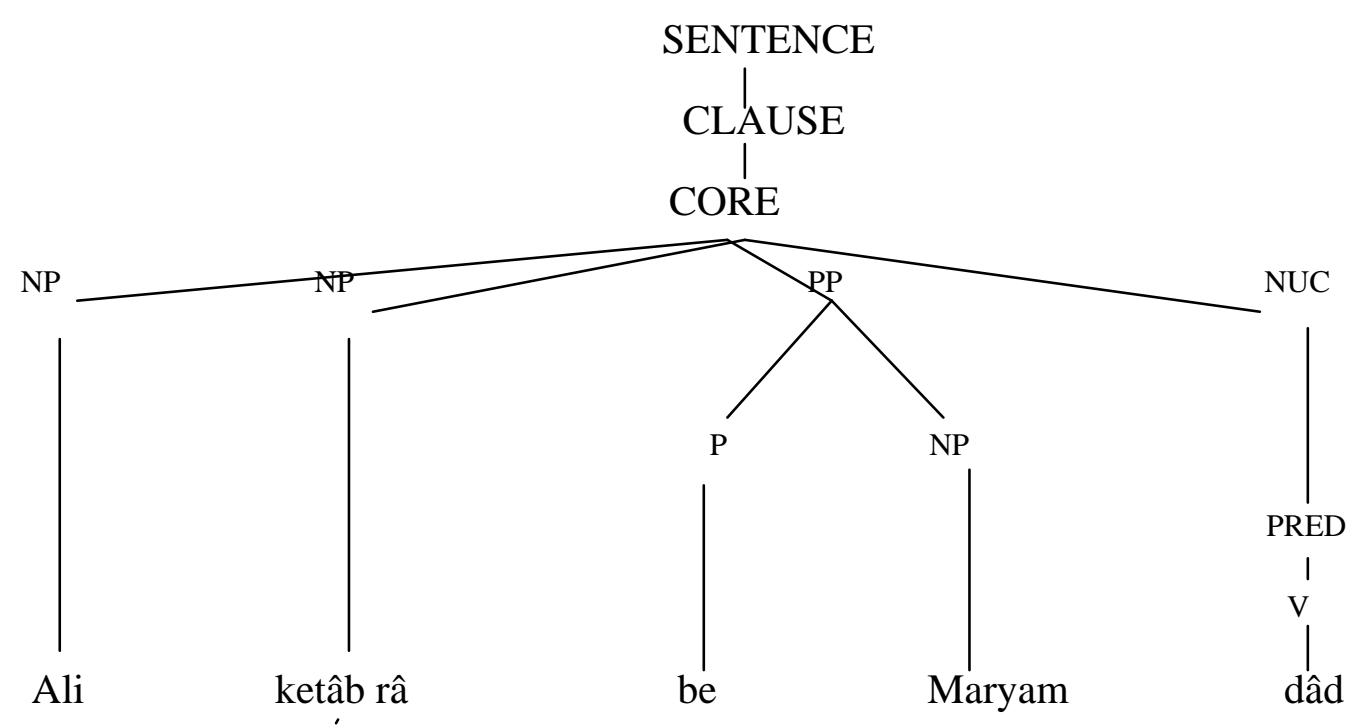

Figure 2. Syntactic representation of an argument -marking prepositional phrase 
The Persian prepositions and prepositional phrases that fall under this category and classification are determined by the meaning of the predicate and are mostly based on direction from/to which the action of the verb happens.

\subsubsection{Predicates Receiving Argument- marking Prepositional Phrases}

There are 9 classes of predicates that receive argument- marking prepositional phrases which will be listed below as (A to I).

\section{Class A}

The following simple verbs take a prepositional phrase as their third argument (oblique core argument): dâdan(give), baxšidan(grant), âmuxtan(learn) ,yâd dâdan(teach), afzudan(add), gereftan(take), porsidan(ask), šenidan(hear), etc.

27) Moallem dars râ be man âmuxt.

teacher lesson DO to me thought.

'The teacher thought the lesson to me.'

The verb âmuxtan has two macrorole arguments (actor and undergoer) and its third argument is non-macrorole which is licensed by the preposition $b e$.

\section{Class B}

Transitive verbs that take the causative morpheme $\hat{a} n$ receive a propositional phrase as their third arguments. These verbs include xorândan(to feed), pušândan(to clothe), fahmândan(to cause to understand) šenâsândan(to make known), tâbândan(to cause to shine),etc.

28) Mâdar lebâs ra be kudak pušand.

mother cloth DO to child clothed.

'Mother clothed the child.'

These verbs have two macrorole arguments and their causative nature enables them to accept the prepositional phrase as their third argument.

\section{Class C}

Verbs that take prepositional phrases as their complement and turn to transitive by the addition of the causative morpheme ân include rahânidan(to save), gozarândan(to pass), časbândan(to paste) etc. as the following sentences show.

29) $\mathrm{U}$ az xatar rahid.

s/he from danger escaped.

'S/he escaped from the danger.'

30) U kudak râ az xatar rahând.

s/he child DO from danger saved. 
'S/he rescued the child from the danger.'

\section{Class D}

Some predicates take a prepositional phrase as direct objects. This is exemplified by the following sentences.

31) Mâšin be daraxt zad.

car to tree hit

'The car hit the tree.'

32) Barâdar-am be man komak kard.

brother-my to me help did.

'My brother helped me.'

These prepositional phrases can be categorized as argument- marking since their preposition is determined by the predicate and the noun phrase that occurs with them is the core argument but unlike other already mentioned sections, the prepositional phrase in these sentences can be considered as the direct argument for the core because it takes the undergoer macrorole.

\section{Class E}

With verbs like ranjidan(to be annoyed), tarsidan(to fear), šekast xordan(to be defeated), farib xordan(to be deceived) etc, a prepositional phrase is used as agent.

33) Kudak az târiki tarsid.

child from darkness feared.

' The child was afraid of darkness.'

34) Došman az mâ šekast khord.

enemy from us defeat hit.

' The enemy was defeated by us.'

The prepositional phrase in (33-34) is the agent and has the actor macrorole so the prepositional phrase in this sentence like those of Class D is considered as the direct argument of core with the difference that those had undergoer macrorole and these have actor macrorole.

\section{Class F}

Some simple verbs take a prepositional phrase as complement. They include andišidan(to think), bâlidan(to boast), pardâxtan(to pay), peyvastan(to join), časbidan(to stick), geravidan(to believe in), tâzidan(to rush), negaristan(to look),etc.This is illustrated by the following sentences.

35) U be pedar-aš mi-bâlad. 


\section{Macrothink}

s/he to father-his IMP- boast.

'S/he boasts of his father.'

36) Dânâ bâ haqiqat ne-mi-jangad.

wise with truth NEG-IMP -fight.

'A wise person does not fight against the truth.'

\section{Class G}

Many of the Persian compound verbs take a prepositional phrase as their second argument. It can be seen from the following examples.

37) Hame az mâ esteqbâl kardand.

all from us welcome did.

'Everybody welcomed us.'

38) Bâ dust-am molâqât kardam.

with friend-my visit did

'I visited my friend. '

Persian has a great number of compound verbs and this is one of its prominent features. They are made up of a noun, an adjective or another component and a verb. Bateni (1996:79). Analyzing the written standard Persian corpuses demonstrated that a great number of the prepositional phrases are actually these predicates arguments.

\section{Class $\mathbf{H}$}

A large number of compound verbs take prepositional phrases as their third argument. The verbs âdat dâdan(to accustom), yâd dâdan(to teach), gozâreš dâdan(to report), nešân dâdan(to show), pas dâdan(to give back) etc, are some other verbs of this group. Like those of group A, as the following sentences show, these verbs take two direct argument and one oblique prepositional phrase argument.

39) Ali Maryam râ bâ Minâ âšti dâd.

Ali Maryam DO with Minâ peace gave.

'Ali reconciled Maryam with Mina.'

40) U mâ râ dar mehmâni bâ ostâd âšnâ kard.

s/he us DO in party with professor familiar did.

'S/he introduced us to the professor in the party.' 


\section{Class I}

The prepositional phrases in the following sentences could be used as source or goal arguments for intransitive verbs of motion. Notice that by taking the prepositional phrases as arguments, the valence of these verbs increases and this, turns them into transitive ones.

41) $U$ be maqsud-e xod resid. s/he to aim-EZ oneself reached.

'S/he attained her/his aim.'

42) Dar tâbestân be yeylâq xâhim raft.

in summer to country will go.

'We will go to the country in summer.'

As can be seen from (42), the prepositional phrase be yeylâq ( to the country)is a complement and can not be omitted from the sentence.

3.3 The Argument-adjunct Prepositional Phrases (+argument), (+core), (+predicative preposition)

A third function of a prepositional phrase valid in role and reference grammar is that it can determine a predicate's argument and yet adds to the meaning of the clause. A good example of this would be a prepositional phrase with a verb like gozâšt ( to put). These verbs need a locational complement but the preposition cannot be determined by the verb itself.

43) Dânešâmuz ketâb ra dar kif-aš gozâšt.

student book DO in bag-his put.

'The student put the book in his bag.'

44) U ketâb râ ruye/zire/kenâre miz gozâšt.

s/he Book DO on/under/beside table put.

'S/he put the book on/under/beside the table .'

As we see in (44) the choice of preposition is not fixed. The choice of preposition affects the meaning, showing that the preposition is predicative. 


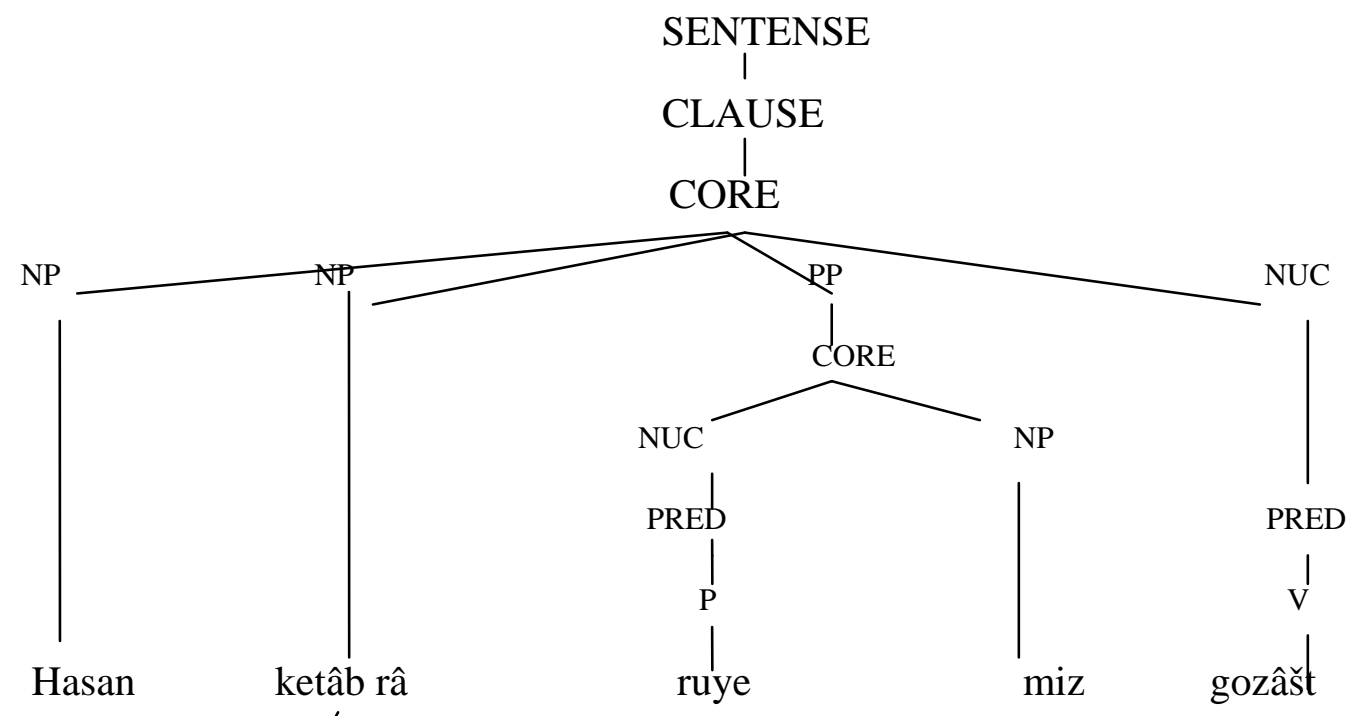

Figure 3. Syntactic representation of an argument -adjunct prepositional phrase

The predicate gozâšt requires three arguments and so all three are core argument, even though one is prepositionally marked.

\section{Conclusion}

In this paper, Persian data including different types of prepositional phrases, used as independent structures were analyzed within the framework of Role and Reference Grammar. It was demonstrated that this classification could be practically applied to analyze the prepositional phrases in Persian. According to this classification, the prepositional phrases are classified into three groups of adjuncts, argument- marking, and argument-adjunct. The argument -marking prepositional phrases were categorized based on nine different Persian predicate types. Though prepositions determine the non-macrorole argument which is neither actor nor undergoer, Persian data shows that some prepositional phrases(D \& E classes) can be macrorole and work as direct core argument. Ultimately, it was demonstrated that Persian prepositional phrases are also used as dependent structures, such as noun complement, adjective, etc.

\section{References}

Arjang, Q. (1996). Dastur-e zabân-e Farsi-e emruz. Tehran: Ghatre publications.

Bateni, M. (1996). Towsife sâxtemân-e dastur-e zabân-e Fârsi. Tehran: Amirkabir publications.

Croft, W. (2001). Radical Construction Grammar. Oxford: Oxford University Press. http://dx.doi.org/10.1093/acprof:oso/9780198299554.001.0001

Dowty, D. (2003). The dual analysis of adjuncts/complements in categorial grammar. Online Available: www.ling.ohio-state.edu/ dowty/papers

Foley, W., \& R. D. VanValin. (1984). Functional Syntax and Universal Grammar. Cambridge University Press. 


\section{Macrothink}

International Journal of Linguistics

ISSN 1948-5425

2012, Vol. 4, No. 4

Gharib, et al. (2002). Dastur Zabâne Fârsi. Tehran:Nahid Publication Company.

Gholâm Alizâdeh, K. (1996), Sâxte zabâane Fârsi.Tehran.Ehya Ketab Publications.

Jolly, Julia, (1993). “Preposition assignment in English.” In VanValin, ed., 275-310.

Michela, C., \& A. Lenci(2011),Gradience in subcategorization?Locative phrases with Italian verbs of motion. Online Available:

ak243.user.srcf.net/gvt/.../sgas2011_abstract_cennamo_lenci.pdf

Pavey, E. (2010) .The Structure of Language :An Introduction to Grammatical Analysis Cambridge University Press.

Radford, A. (1997). Syntactic Theory and The Structure of English .Cambridge University Press. http://dx.doi.org/10.1017/CBO9781139166706

Rezai, Vali. (2003). A Role and Reference Grammar Analysis of Simple Sentences in Persian (Modern Persian).Ph.D. Dissertation, University of Isfahan.

Silvia, L., \& C. Parodi.(2008). Key terms in syntax and syntactic theory. London:Continuum International publishing group.

Van Valin, \& Robert D. (2005). Exploring the Syntax- Semantics Interface. Cambridge University Press.

Van Valin, Robert D. \& Randy J. Lapolla. (1997). Syntax : Structure , Meaning and Function. Cambridge University Press. http://dx.doi.org/10.1017/CBO9781139166799

Van Valin, \& Robert D. (1991). Functionalist Linguistic Theory and Language Acquisition. First Language, 11, 7-40. http://dx.doi.org/10.1177/014272379101103102

Van Valin, \& Robert D. (2001). An Introduction to Syntax. Cambridge University Press.

VanValin, \& Robert D. (ed.). (2008). Investigations of the Syntax-Semantics-Pragmatics Interface. Cambridge University Press.

VanValin, Robert D., \& William, Foley. (1980). “Role and Reference Grammar.” In Moravcik and Wirth, eds., 329-52.

VanValin, Robert D. (1993). Advances in Role and Reference Grammar. John Benjamin. 